\title{
Evaluation Research of Food Safety State Based on the Improved Fuzzy Information Axiom Model
}

\author{
ZHANG Biao ${ }^{1}$, CAI Jiu-yan ${ }^{1}$, YANG Jie $^{2}$ \\ ${ }^{1}$ Quality Development Institute of Kunming University of Science and Technology, Kunming, Yunnan, 650093, China \\ ${ }^{2}$ The Government of Yunnan Province Comprehensive Office, Kunming, Yunnan, 650000, China \\ 997630650@qq.com
}

\begin{abstract}
The evaluation of food safety state means to assess risk factors regarding the safety of food, and to finalize the security state of food. This report illustrates two factors: the healthy index affecting the food safety state and the sensory index reflecting its status. In order to establish the evaluation index system of food safety, the article uses the improved method of fuzzy information axiom for better evaluating the food safety state. Finally, in ham sausage, for example, proves that the sample $\mathrm{A}$ is the best.
\end{abstract}

Index Terms - food safety state, fuzzy information axiom, evaluation

\section{Introduction}

As repeated food safety problems arise, more and more people pay attention to food safety state. Considering the superficial and potential damage factors, food safety state refer to the degree of negative factors in food to the consumers' health in a country or region over a certain time[1]. According to the related regulation of Food Safety Law of the People's Republic of China, hazardous matter content should be controlled within the limited range of food safety standard in the process of food production and circulation, to ensure the safety of the public health and life. That is to say, the parameters of factors influencing food safety state should conform to the requirements of the food safety standards. In view of this, correct assessment of food safety state is extremely essential. Based on the collection of information on factors influencing food safety, evaluation of food safety state works out the judgmental description of the current food safety state, and finally the priority ordering[2]. Scientific and appropriate evaluation of food safety state, not only can provide the correct information for consumers, ensuring the life and health, but also can provide the decision-making basis for food safety management function.

About studies of food safety state evaluation, scholars at home and abroad have done a considerable amount of work. Generally, the studies include the construction of assessment index system of food safety state and the use of evaluation method. In the design of index system, most of the scholars based on the physical, chemical and biological contamination damage design micro measurable factors as evaluation indexes[3-7], mainly including bacteria, harmful microbial contamination, heavy metal poisoning, agriculture and veterinary drug residue, and the abuse of food additive, etc. These indicators are fair and detailed, and they certainly could reflect the current state of food. However, these indicators are single and one-sided in a certain sense. In the evaluation system, various methods and mathematics models were established. In overseas, such methods as biologically based dose response models, probabilistic approach, deterministic approach and relative potency factor systems were used, moreover, dietary risk assessments of exposure to chemicals and organisms were concernedly performed[8]. In China, such methods as analytic hierarchy process combined with grey correlation analysis method, extended rough set model and toxicological analysis were used extensively, besides, fuzzy comprehensive evaluation method was adopted by more scholars[9]. The starting point of all kinds of evaluation method is different, and the applicable objects are different, so these methods have their advantages and disadvantages. Suh's Axiomatic Design Theory provides a alternative evaluation method[10], and this theory could assess the quantitative index. Combined with the fuzzy evaluation process, the model may carry on the appropriate estimation of qualitative indicators. Quantitative indexes and qualitative indexes can be assessed reasonably by the combination of the two methods.

In view of this, through reference to national food hygiene legislation, HACCP standard practice, and on the basis of predecessors' research results[11,12], author formulates a number of technical and analytical evaluation index system of food safety state in this article. Through the application of the improved fuzzy information axiom of evaluation methods, combined with concrete examples, it concludes that the food safety state of sample A is the best. Author carries out the specific evaluation process and proves that this method is relevant and applicable in the assessment of the food safety state.

\section{The Design of Evaluation Index System of Food Safety State}

\subsection{The concept of index design}

It is necessary to understand some principles of index design. Starting from the connotation of food safety state, the general principles such as technical nature, feasibility, completeness, measurability, importance must be followed[13]. What's more, the principles of food sensory index design such as the characteristic, the correspondence and the combination of qualitative and quantitative need be followed about the food sensory evaluation[14].

1. The characteristic principle: the indicators need reflect the characteristics of the food state.

2. The correspondence principle: the characteristics of some sensory indexes is the independent implementation of health indicators, so two kinds of index need to be able to 
explain, enhance and support each other.

3. The combination of qualitative and quantitative: qualitative index needs not only qualitative description, but also needs to be defined by quantitative parameters for quantitative evaluation reasonably.

\subsection{The construction of index system}

Food safety state refers to the influence degree of harm to the health of consumers. Through the study of national standard and related documentation, the article sums up the indicators of food safety state typically include: health indexes and sensory indicators. Health index refers to that some factors can ensure the most basic food safety, including toxins, microbes, heavy metals, etc.. It is the bottom line of ensuring food safety state and determines the safe state of food. Sensory indicator refers to that ones can reveal the sensory characteristics of food, such as appearance, smell and texture. Sensory indexes not only can meet the demands of edible, can also indicate the state of food safety[15].

In view of the building evaluation index system of food safety state, the construction of index system can use the conventional method for reference. The general evaluation system can be divided into overall layer, criterion layer and index layer[16]. On the evaluation system of food safety state, its overall layer should carry out the food safety state level of a certain species, nation or region. Criterion layer is the concept category affecting the state of food safety, and through the above analysis, the criterion layer can be divided into health index and sensory indicator. Index layer is the primary evaluation index in the evaluation system, will essentially reflect the different aspects of the food safety state. As following, a total of 11 quantitative and qualitative basic indexes obtained.

Evaluation index system of food safety state as shown in the Fig. 1:

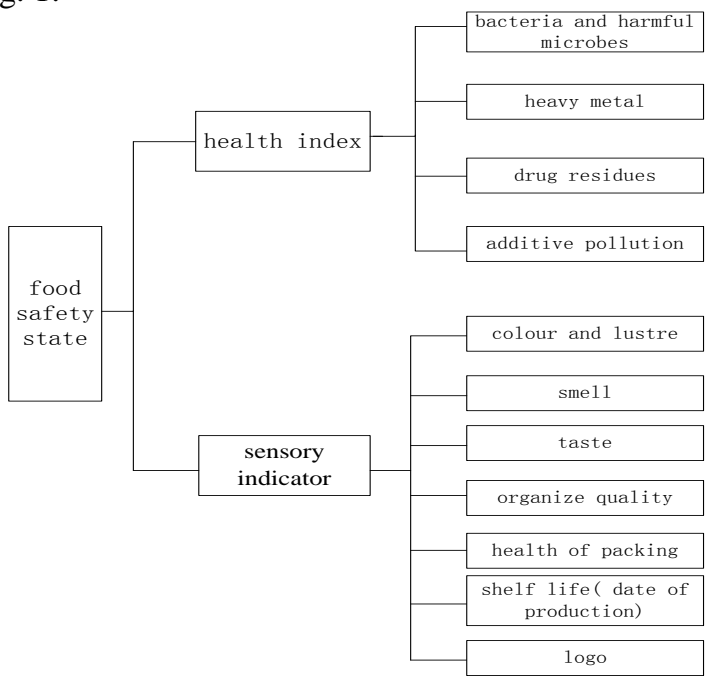

Fig.1 Evaluation index system of food safety state

Qualitative indexes need be described by quantitative language, so the linguistic scale shows in the Table 1:

In order to determine the qualitative indexes more accurately, the linguistic scale should be translated into data.
According to the Table 1, the data are designed to be 5 points. The linguistic scale is assigned values of 1-5 in turn, and the values in Table 2 correspond to the ones in Table 1.

TABLE 1 The linguistic scale of the qualitative indexes

\begin{tabular}{|c|c|c|c|c|c|}
\hline Index & \multicolumn{5}{|c|}{ Linguistic scale } \\
\hline colour & very good & good & common & bad & very bad \\
\hline smell & $\begin{array}{c}\text { very } \\
\text { normal }\end{array}$ & normal & common & abnormal & $\begin{array}{c}\text { very } \\
\text { abnormal }\end{array}$ \\
\hline taste & $\begin{array}{c}\text { very } \\
\text { normal }\end{array}$ & normal & common & abnormal & $\begin{array}{c}\text { very } \\
\text { abnormal }\end{array}$ \\
\hline $\begin{array}{c}\text { organize } \\
\text { quality }\end{array}$ & very good & good & common & bad & very bad \\
\hline $\begin{array}{c}\text { packing } \\
\text { health }\end{array}$ & very clean & clean & common & dirty & very dirty \\
\hline $\begin{array}{c}\text { shelf life } \\
\text { interval } \\
1 / 5\end{array}$ & $\begin{array}{c}\text { interval } \\
2 / 5\end{array}$ & $\begin{array}{c}\text { interval } \\
3 / 5\end{array}$ & $\begin{array}{c}\text { interval } \\
4 / 5\end{array}$ & $\begin{array}{c}\text { interval } \\
5 / 5\end{array}$ \\
\hline logo & very clear & clear & common & unclear & no marks \\
\hline
\end{tabular}

TABLE 2 The value of the linguistic scale

\begin{tabular}{|c|c|c|c|c|c|}
\hline & \multicolumn{5}{|c|}{ value } \\
\hline Index & 1 & 2 & 3 & 4 & 5 \\
\hline
\end{tabular}

\section{Fuzzy information axiom model}

\subsection{Axiomatic design}

Axiomatic Design (AD) proposes to formulate a scientific and systematic basis that provides structure to design process for engineer. The primarily purpose of $\mathrm{AD}$ is to provide a thinking process to create a new design and/or to improve the existing design [17].

Axiom 1. The Independence Axiom

Statement 1. An optimal design always maintains the independence of functional requirements (FRs)

Statement 2. In an acceptable design, the design parameters(DPs) and FRs relate in such a way that specific DP can be adjusted to meet its Corresponding FR without affecting other FR.

Axiom 2. The Information Axiom

Statement. The perfect design is a functionally uncoupled design that has the minimum information content.

Axiomatic design uses success probability of design parameters meeting the functional requirements for expressing satisfaction of policymakers, then, the probability is translated into the amount of information by some formulas, selecting the least amount of information for the best solution. However, information axiom can only work out the amount of information of exact numerical indicators. So combining the fuzzy mathematics method, the method can include the linguistic scale of qualitative indexes translated into data. At last, the model overcomes the weakness that qualitative indexes information is difficult to calculate in traditional information axiom and makes the evaluation and decisionmaking more accurate.

\subsection{The information content of quantitative index}

The information axiom (IA) is a conventional method and facilitates the selection of proper alternative. In other word, information axiom helps the independence axiom to put forth 
the best design. The information axiom symbolized by the information content relates to the probability to satisfy the design goals[18]. The information content (I) given by (1).

$$
I_{i}=\log _{2} \frac{1}{P_{i}}
$$

Fig.2 illustrates the calculation procedures for the probability of achieving the design goal for only one FR.

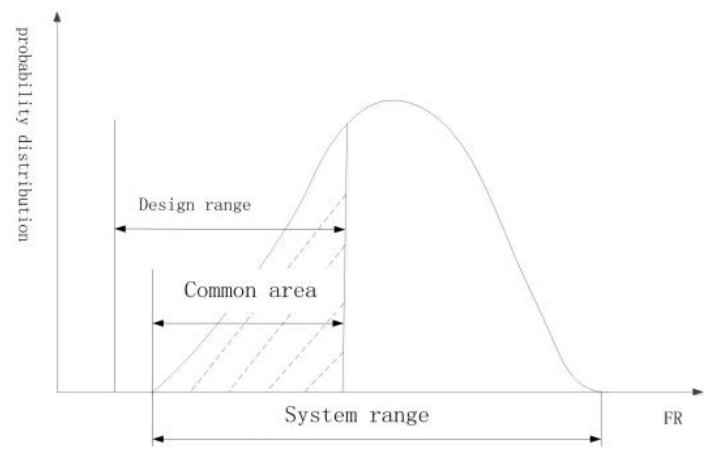

Fig.2 The relationship among design range, common area, and system range

In practice, it is often difficult to calculate successful probability of meeting the functional requirements directly. In the recent studies, Kulak and Kahraman [19, 20]extended the information axiom under fuzzy environment, and the new methodology is used for the solution of decision making problems under fuzzy environment. Both system and design ranges consist of triangular fuzzy numbers(TFN). Therefore, the probability calculated by (2) and information content calculated by (3)

$$
\begin{aligned}
& P_{i}=\frac{\text { Common Area }}{\text { TFN of System Design }} \\
& I_{i}=\log _{2} \frac{\text { TFN of System Design }}{\text { Common Area }}
\end{aligned}
$$

Fig. 3 illustrates the information content calculation procedure with triangular fuzzy numbers.

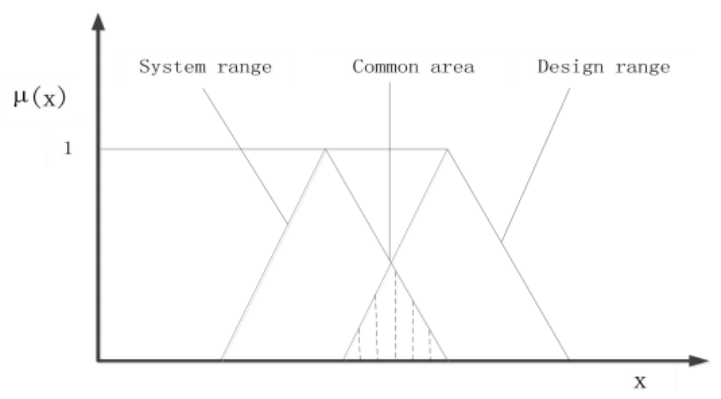

Fig.3 The common area of the system and design ranges.

When the design range and evaluation indexes are the quantitative expression, according to the statistical distribution, the exponential distribution density function can be used. That is to abide by $P_{i}=e^{-\left[y_{i}-y_{0}\right]}, y_{0}$ indicate the function value, $y_{i}$ represent the design value of alternatives.

When the design values of alternatives requested to be equal or greater than the functional requirements, information content is calculated as follow.

$$
I_{i}=\log _{2} e^{\left|y_{i}-y_{0}\right|}
$$

On the contrary, In the food safety state evaluation, when the design values of the alternatives is requested to be less than functional requirements as much as possible, information content is calculated as follow.

$$
I_{i}=-\log _{2} e^{\left|y_{i}-y_{0}\right|}
$$

\subsection{The amount of information of qualitative index}

Qualitative indexes need to be numerical analysis, and the study choose fuzzy membership function to deal with the parameter. Triangular fuzzy unit is easy to use, and can show different kinds of fuzzy variables, so this paper uses triangular fuzzy number to scale the qualitative indexes.

Considering the aspect of the evaluation index system of food safety state, the evaluation system requires linguistic values of qualitative indexes as greater as possible, possessing the benefit attributes. Suppose the function worthy of an indicator is 'common' in A solution and 'good' in B solution, then the design requirements is more than 'common', so the design range is a whole area more than 'common' as shown in Fig. $4 \mathrm{a}$ and $4 \mathrm{~b}$.

System choice is included in the design scope, and normal choice is equal to the triangular fuzzy numbers of system range. According (3), information contents of two solutions are all equal to 0 . They are the same, but the $\mathrm{B}$ solution should be better than A obviously. In order to solve this problem, it is necessary to redefine the calculation formula of information content.

In terms of benefit attributes, the TFN of good value actually contains the part of scope that is bigger than its. Such as Fig.4b, its TNF of system range should be shown in the Fig.4c.

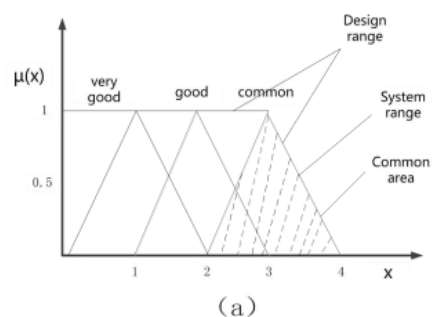

(a)

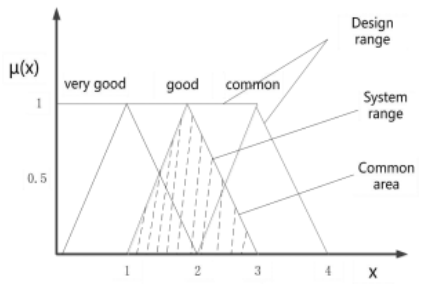

(b)

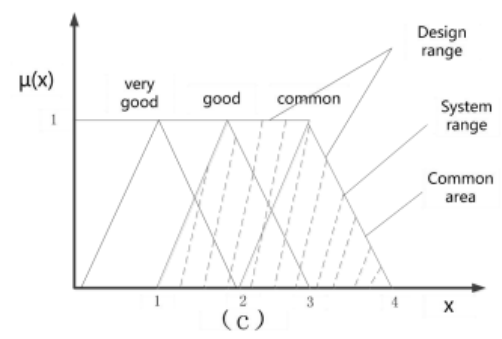

Fig.4 Membership function curve of the system and design range for benefit attributes

It is necessary to emphasize that the design range is settled up according to expectations of customers, meaning the 
functional requirement of the customer. For the same alternative offer, different customers have different requirements, namely the assessment aimed at requirements of customers. So successful probability can be expressed to (6), and the calculation formula of information content rewritten as (7).

$$
\begin{gathered}
P_{i}=\frac{\text { Common area }}{\text { TFN of Design Range }} \\
I_{i}=\log _{2} \frac{\text { TFN of Design Range }}{\text { Common Area }}
\end{gathered}
$$

Given the different nature of each evaluation index, generally different indicators have different dimension and level of magnitude. After calculating the index information contents by the above formula and in order to guarantee the reliability of the results, it is necessary to deal with the original data of information content by standardization method. Then carry out the total information content on the basis of (8). Supposing there are $m$ factor indexes, the total information content is the sum of each information content.

$$
I_{i}=I_{1}+I_{2}+\ldots+I_{m}
$$

\subsection{Evaluation process of the fuzzy information axiom}

In this section, the main steps of the methodology in the evaluation of the food safety state are given as follow. Step 1 : Determining evaluation indexes system. For the qualitative indicators, the linguistic scale should be setted up, and then translated into data. Step 2: Determining the design and system range of each evaluation index, and using triangular fuzzy number to work out the membership function curve. Step 3: Analyzing the nature of the evaluation index, if it is quantitative said, using (5) calculate directly; if it is qualitative said, Equation (7) should be used to calculate. Step 4. Repeating step 3, carrying out the information concent of each index, then dealing with the data by standardization method, besides, calculating the total information content according to (8). Finally, choosing the minimum information content for the optimal solution.

\section{Application Example}

Ham sausage is a kind of meat food that is delicious, easy to carry, and has long shelf life, but with the events happening, such as the clenbuterol and the expired meat, consumers pay more and more attention to the security state of the ham sausage. Some data of three kinds of hum sausage is shown in Table 3, including a part of test data about health indicators and the limit of the standard regulations. The results of experts' perception and consumer demands to the indicators are shown in Table 7. index

(1)The information concent calculation of quantitative

According to the nature of indicators, the information concent of quantitative index should be calculated by (5). To save space, there is not the calculation process, only listing the

\begin{tabular}{|c|c|c|c|c|c|}
\hline & \multirow{2}{*}{ Index } & Sample A & Sample B & Sample C & \multirow{2}{*}{$\begin{array}{c}\text { Standard } \\
\text { limit }\end{array}$} \\
\hline & & Test data & Test data & Test data & \\
\hline \multirow[b]{2}{*}{$\begin{array}{l}\text { Microorga } \\
\text { nism }\end{array}$} & $\begin{array}{l}\text { Pathogenic } \\
\text { bacteria }\end{array}$ & 0 & 0 & 0 & 0 \\
\hline & \begin{tabular}{|l|} 
Coliform \\
group(MPN/10 \\
0g)
\end{tabular} & 5 & 11 & 18 & 30 \\
\hline \multirow{3}{*}{$\begin{array}{l}\text { Heavy } \\
\text { metal }\end{array}$} & $\mathrm{Pb}(\mathrm{mg} / \mathrm{kg})$ & 0.11 & 0.13 & 0.18 & 0.5 \\
\hline & Cd(mg/kg) & 0 & 0 & 0.01 & 0.1 \\
\hline & \begin{tabular}{|l|}
$\mathrm{Hg}(\mathrm{mg} / \mathrm{kg})$ \\
\end{tabular} & 0 & 0.01 & 0 & 0.05 \\
\hline \multirow{3}{*}{ Additive } & $\begin{array}{l}\text { 2,4-Hexadie- } \\
\text { noic acid(g/kg) }\end{array}$ & 0.4 & 0.8 & 0.7 & 1.5 \\
\hline & \begin{tabular}{|l} 
Sodium \\
nitrite $(\mathrm{g} / \mathrm{kg})$
\end{tabular} & 0.015 & 0.017 & 0.020 & 0.030 \\
\hline & \begin{tabular}{|l} 
Allura \\
red(g/kg)
\end{tabular} & 0.006 & 0.010 & 0.010 & 0.015 \\
\hline Drug & $\begin{array}{l}\text { O-dimethyl-O- } \\
2 \text { (mg/kg) }\end{array}$ & 0 & 0 & 0 & 0.01 \\
\hline
\end{tabular}
results of the information concent, as shown in Table 4.
TABLE 3 The test data and standard requirements

\begin{tabular}{|c|c|c|c|c|}
\hline \multicolumn{2}{|r|}{ Index } & $\begin{array}{l}\text { Information } \\
\text { concent of A }\end{array}$ & $\begin{array}{l}\text { Information } \\
\text { concent of B }\end{array}$ & $\begin{array}{l}\text { Information } \\
\text { concent of C }\end{array}$ \\
\hline \multirow{2}{*}{$\begin{array}{l}\text { Microor } \\
\text { ganism }\end{array}$} & $\begin{array}{c}\text { Pathogenic } \\
\text { bacteria }\end{array}$ & 0 & 0 & 0 \\
\hline & $\begin{array}{c}\text { Coliform } \\
\text { group(MPN/100g) }\end{array}$ & -36 & -27 & -17 \\
\hline \multirow{3}{*}{$\begin{array}{l}\text { Heavy } \\
\text { metal }\end{array}$} & $\mathrm{Pb}(\mathrm{mg} / \mathrm{kg})$ & -0.56 & -0.53 & -0.46 \\
\hline & Cd(mg/kg) & -0.14 & -0.14 & -0.13 \\
\hline & $\mathrm{Hg}(\mathrm{mg} / \mathrm{kg})$ & -0.07 & -0.06 & -0.07 \\
\hline \multirow{3}{*}{$\begin{array}{c}\text { Additiv } \\
\mathrm{e}\end{array}$} & $\begin{array}{l}\text { 2,4-Hexadie-noic } \\
\text { acid(g/kg) }\end{array}$ & -1.59 & -1.01 & -1.15 \\
\hline & $\begin{array}{c}\text { Sodium } \\
\text { nitrite }(\mathrm{g} / \mathrm{kg})\end{array}$ & -0.022 & -0.019 & -0.014 \\
\hline & Allura red(g/kg) & -0.013 & -0.007 & -0.007 \\
\hline Drug & $\begin{array}{l}\text { O-dimethyl-O- } \\
2(\mathrm{mg} / \mathrm{kg})\end{array}$ & -0.014 & -0.014 & -0.014 \\
\hline
\end{tabular}

TABLE 4 The information concent of quantitative index

The data through $0-1$ standardized processing is shown in Table 5.

TABLE 5 The data through 0-1 standardized processing

\begin{tabular}{|l|l|c|c|c|}
\hline \multicolumn{2}{|c|}{ Index } & $\begin{array}{c}\text { Information } \\
\text { concent of A }\end{array}$ & $\begin{array}{c}\text { Information } \\
\text { concent of B' }\end{array}$ & $\begin{array}{c}\text { Information } \\
\text { concent of C' }\end{array}$ \\
\hline \multirow{2}{*}{$\begin{array}{l}\text { Microorg } \\
\text { anism }\end{array}$} & Pathogenic bacteria & 0 & 0 & 0 \\
\cline { 2 - 5 } & $\begin{array}{l}\text { Coliform } \\
\text { group(MPN/100g) }\end{array}$ & -0.982 & -0.035 & 1.017 \\
\hline \multirow{2}{*}{$\begin{array}{l}\text { Heavy } \\
\text { metal }\end{array}$} & Pb(mg/kg) & -0.844 & -0.260 & 1.104 \\
\cline { 2 - 5 } Additive & Cd(mg/kg) & -0.577 & -0.577 & 1.155 \\
\cline { 2 - 5 } & $\begin{array}{l}\text { Hg(mg/kg) } \\
\text { acid(g/kg) }\end{array}$ & -0.577 & 1.155 & -0.577 \\
\cline { 2 - 5 } & $\begin{array}{l}\text { Sodium nitrite } \\
\text { (g/kg) }\end{array}$ & -1.123 & 0.793 & 0.330 \\
\cline { 2 - 5 } & Allura red(g/kg) & -1.155 & -0.165 & 1.072 \\
\hline \multirow{2}{*}{ Drug } & $\begin{array}{l}\text { O-dimethyl-O- } \\
\text { 2(mg/kg) }\end{array}$ & 0 & 0 & 0.577 \\
\hline
\end{tabular}

Comprehensive the above, the information concent result of quantitative index is shown as follow. 
TABLE 6 The information concent result of quantitative index

\begin{tabular}{|c|c|c|c|}
\hline Index & $\begin{array}{c}\text { Information } \\
\text { concent of A' }\end{array}$ & $\begin{array}{c}\text { Information } \\
\text { concent of B' }\end{array}$ & $\begin{array}{c}\text { Information } \\
\text { concent of C' }\end{array}$ \\
\hline Microorganism & -0.982 & -0.035 & 1.017 \\
\hline Heavy metal & -1.998 & 0.318 & 1.682 \\
\hline Additive & -3.185 & 1.205 & 1.979 \\
\hline Drug & 0 & 0 & 0 \\
\hline
\end{tabular}

(2) The information concent calculation of qualitative index

For qualitative indicators, it needs to be described to the linguistic scale, then translated into data. The paper makes the linguistic scale divide into 5 grades, and assigns for 1,2,3,4,5. After determining the design and system scope of each index, it need draw up the triangular membership function curve of each indicator, and uses fuzzy information axiom method to calculate the information concent of the index.

TABLE 7 The experts' perception and consumer demands

\begin{tabular}{|c|c|c|c|c|}
\hline \multirow{2}{*}{ Index } & Sample A & Sample B & Sample C & \multirow{2}{*}{ Requirement } \\
\cline { 2 - 4 } & $\begin{array}{c}\text { Linguistic } \\
\text { scale }\end{array}$ & $\begin{array}{c}\text { Linguistic } \\
\text { scale }\end{array}$ & $\begin{array}{c}\text { Linguistic } \\
\text { scale }\end{array}$ & \\
\hline Colour & Good & Good & Common & Good \\
\hline Smell & $\begin{array}{c}\text { Very } \\
\text { normal }\end{array}$ & $\begin{array}{c}\text { Very } \\
\text { normal }\end{array}$ & Common & Clean \\
\hline Taste & $\begin{array}{c}\text { Very } \\
\text { normal }\end{array}$ & $\begin{array}{c}\text { Very } \\
\text { normal }\end{array}$ & Common & Clean \\
\hline Organize quality & Good & Good & Common & Good \\
\hline Packing health & Clean & Common & Very clean & Clean \\
\hline $\begin{array}{c}\text { Shelf life( data } \\
\text { of production) }\end{array}$ & Interval 2/5 & Interval $1 / 5$ & Interval 4/5 & Interval 3/5 \\
\hline Logo & Very clear & Clear & Clear & Very clear \\
\hline
\end{tabular}

Color index, for example, to calculate the information concent, its triangular membership function curve as shown in Fig.5.

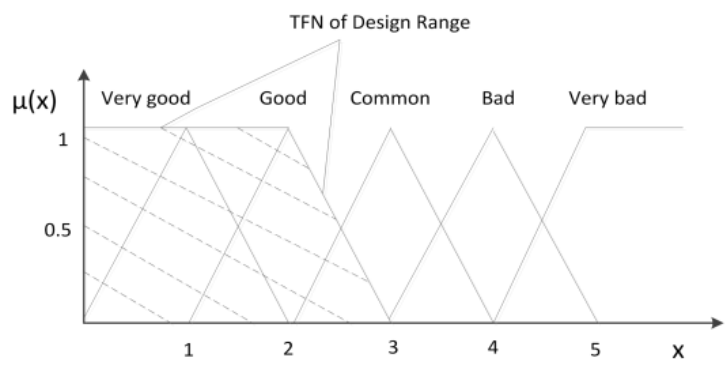

Fig.5 The triangular membership function curve of the color

The calculation of the information concent of A color is followed.

$$
\begin{aligned}
& I_{A C}=\log _{2}(2.5 / 1)=1.322 \\
& I_{B C}=\log _{2}(2.5 / 1)=1.322 \\
& I_{C C}=\log _{2}(2.5 / 0.25)=3.322
\end{aligned}
$$

The rest of the index calculation results shown in Table 8.
TABLE 8 The information content of qualitative indicators

\begin{tabular}{|l|c|c|c|}
\hline \multicolumn{1}{|c|}{ Index } & $\begin{array}{c}\text { Information } \\
\text { concent of A }\end{array}$ & $\begin{array}{c}\text { Information } \\
\text { concent of B }\end{array}$ & $\begin{array}{c}\text { Information } \\
\text { concent of C }\end{array}$ \\
\hline Colour & 1.322 & 1.322 & 3.322 \\
\hline Smell & 0.322 & 0.322 & 3.322 \\
\hline Taste & 0.322 & 0.322 & 3.322 \\
\hline Organize quality & 1.322 & 1.322 & 3.322 \\
\hline Packing health & 1.322 & 3.322 & 0.322 \\
\hline Shelf life (data of production) & 0.807 & 0.222 & 3.807 \\
\hline Logo & 0.585 & 2.585 & 2.585 \\
\hline
\end{tabular}

The data through 0-1 standardized processing shown in Table 9.

TABLE 9 The data through $0-1$ and the standardized processing

\begin{tabular}{|l|c|c|c|}
\hline \multicolumn{1}{|c|}{ Index } & $\begin{array}{c}\text { Information } \\
\text { concent of } \\
\text { A }^{\prime}\end{array}$ & $\begin{array}{c}\text { Information } \\
\text { concent of } \\
\text { B }^{\prime}\end{array}$ & $\begin{array}{c}\text { Information } \\
\text { concent of } \\
\text { C' }^{\prime}\end{array}$ \\
\hline Colour & -0.577 & -0.577 & 1.155 \\
\hline Smell & -0.577 & -0.577 & 1.155 \\
\hline Taste & -0.577 & -0.577 & 1.155 \\
\hline Organize quality & -0.577 & -0.577 & 1.155 \\
\hline Packing health & -0.218 & 1.091 & -0.873 \\
\hline Shelf life( data of production) & -0.419 & -0.723 & 1.141 \\
\hline Logo & -1.155 & 0.577 & 0.577 \\
\hline
\end{tabular}

Combined with the data in Table 6 and Table 9, $I_{A}=-$ 10.267, $I_{B}=0.124, I_{C}=10.143$.

See from the calculation results, sample $A$ has the smallest information content, thus, safety state of ham A is the best. This evaluation results conform to the actual situation.

\section{Conclusion}

According to the connotation of food safety state, the paper considers synthetically two aspects, including hygiene indexes sensory indexes and analyzes the inner factors influencing food safety state and intuitive factors that can reflect the food safety state, then builds up a set of new evaluation index system of food safety state. The evaluation theory of fuzzy information axiom is used in this study. In order to make it relevant to the evaluation of the food safety state, the process of calculation is given reasonable advance and adds a process of dealing with the data by standardization method, making evaluation result more scientific and proven. Finally, the results in the case of ham

sausage, shows that evaluation process based on fuzzy information axiom can effectively assess the food safety state, and proves that fuzzy information axiom model in the field of food safety evaluation is applicative and operable and has a positive popularization value.

\section{Acknowledgment}

We would like to express our gratitude to all those who have helped us during the writing of this paper. We also deeply appreciate the helpful review comments and suggestions by anonymous reviewers. 


\section{References}

[1] Sh.-X. Du, Sh.-P.Han, Comprehensive assessment of the food safety state based on fuzzy evaluation method. Journal of Chinese Institute of Food Science and Technology 2006, 6:64-69. (In Chinese)

[2] Z.-Y. Zhou, Y.-B. Pan, M.-J. Wang, Fuzzing mathematic method in the comprehensive assessment of food contamination. Environmental Science, 2000, 21(3): 22-26.

[3] NY5115-2008 The Pollution-Free Food Rice[S]. (In Chinese)

[4] P. Zhu, Y. Luo, H. Tan ed., The study of early warning model about quality safety of rice food. Journal of Food Safety and Quality, 2010, 27(4):161-163. (In Chinese)

[5] A. Lammerding, Foodborne Infections and Intoxications (Fourth Edition). Food Science and Technology, 2013.

[6] H.J. Hamasalim, H.N. Mohammed, Determination of heavy metals in exposed corned beef and chicken luncheon that sold in Sulaymaniah markets. African Journal of Food Science, July 2013:178-182

[7] Robert R. Maronpot, J. Davis, Evaluation of 90-day oral rat toxicity studies on the food additive, gum ghatti. Food and Chemical Toxicology, 2013,51: 215-224

[8] Harvey J. Clewell, Russell S. Thomas, Gentry P. Robinan ed., Research toward the development of a biologically based dose response assessment for inorganic arsenic carcinogenicity: A progress report. Toxicology and Applied Pharmacology, 2007, 222: 388-398.

[9] R.-F. Bo, H.-Zh. Huang, Application of interactive fuzzy physical programming in multi-objective decision making for concept selection. Journal of Basic Science and Engineering, 2005,13(4):422-450

[10] N P. Suh, Axiomatic Design: Advances and Applications. Oxford: Oxford University Press, 2001.
[11] J.-H. Xie, M.-Y. Shen, Ch. Li, Current status and countermeasures on food safety in China. Food Engineering, 2010, 3:9-12. (In Chinese)

[12] H. Yang, HACCP system and our country's food security. Packaging and Food Machinery, 2008,26(2):52-59. (In Chinese)

[13] Zh.-M. Li, Research on establishment of the food security evaluation indicator system and its demonstration. Issues in Agricultural Economy, 2009:84-89. (In Chinese)

[14] L. Zhao, W. Liu, H.-Y. Wang, General guidance and method for establishing index system of food sensory evaluation. Journal of Chinese Institute of Food Science and Technology, 2008, 8(3):121-124. (In Chinese)

[15] J. Zhu, F.-F. Lv, Development of study on sensory evaluation in food. China Condiment, 2009, 34(5):29-49. (In Chinese)

[16] L.-X. Zhang, X. Liu, D.-L. Li ed., Evaluation of the rural informatization level in four Chinese regions: A methodology based on catastrophe theory. Mathematical and Computer Modeling, 2013, 58:868-876. (In Chinese)

[17] N P. Suh, Complexity Theory and Applications, Oxford University Press, NY, 2005.

[18] N P. Suh, The Principles of Design, Oxford University Press Inc., NY, 1990.

[19] O. Kulak, C. Kahraman, Fuzzy multi-attribute selection among transportation companies using axiomatic design and analytic hierarchy process, Information Sciences, 2005, 170: 191-210.

[20] O. Kulak, C. Kahraman, Multi-attribute comparison of advanced manufacturing systems using fuzzy vs. crisp axiomatic design approach, International Journal of Production Economics, 2005, 95: 415-424. 